\title{
The Mediating Role of Motivation Between Brand Citizenship Behavior and Employee Performance: A Study of Supervisors' Perception
}

\author{
Marwan GHALEB iD a Güven ORDUN ${ }^{\text {iD }}$ b \\ a Istanbul University, Institute of Social Sciences, Department of Business Administration, Istanbul, Turkey. \\ marwan.m.ghaleb@gmail.com \\ b Istanbul University, Faculty of Business Administration, Department of Organizational Behavior, Istanbul, Turkey. \\ gordun@istanbul.edu.tr
}

\begin{tabular}{|c|c|}
\hline ARTICLE INFO & ABSTRACT \\
\hline $\begin{array}{l}\text { Keywords: } \\
\text { Brand citizenship } \\
\text { behavior } \\
\text { Intrinsic motivation } \\
\text { Extrinsic motivation } \\
\text { Employee performance }\end{array}$ & $\begin{array}{l}\text { Purpose - The purpose of this research is to study the direct impact of brand citizenship behavior on } \\
\text { employees' performance, as well as its indirect effect, having intrinsic and extrinsic motivations as } \\
\text { mediators, for employees working in international franchised branded organizations operating in Yemen. } \\
\text { Design/methodology/approach - The research targeted supervisors that have subordinates under their } \\
\text { supervision. They were asked to answer a survey questioner based on their observations of their } \\
\text { subordinates' behavior. } 207 \text { responses were accepted to participate in the research analysis, which was } \\
\text { conducted using structural equational modeling. }\end{array}$ \\
\hline $\begin{array}{l}\text { Received } 3 \text { February } 2021 \\
\text { Revised } 16 \text { April } 2021 \\
\text { Accepted } 5 \text { June } 2021\end{array}$ & $\begin{array}{l}\text { Findings - It has been found that there is a direct impact of brand citizenship behavior on employee } \\
\text { performance. It was also found that intrinsic motivations have the only mediating role between brand } \\
\text { citizenship behavior toward employee performance, on the other hand, no mediation role was found for } \\
\text { extrinsic motivations. }\end{array}$ \\
\hline $\begin{array}{l}\text { Article Classification: } \\
\text { Research Article }\end{array}$ & $\begin{array}{l}\text { Discussion - This research has combined the branding field and organizational behavior field. It } \\
\text { contributes to the internal brand management field besides employee performance management, by } \\
\text { presenting insights to management in their internal branding strategies and employee motivators. On the } \\
\text { other hand, it provides subordinates an overview of their supervisors' perceptions. }\end{array}$ \\
\hline
\end{tabular}

\section{Introduction}

Employees are one of the organizations' valuable resources, their collective efforts and performance help the organizations to move forward and achieve targeted goals. Employees' performance is a key factor for the organizations' successes, as it is linked with their overall organizational performance, and accomplishing results, it is considered as a competitive advantage of an organization that cannot be imitated by other competitors (Alefari et al., 2018; Rusu et al., 2016; Abbas \& Yaqoob, 2009). Committed employees, who present high standard performance, provide their organizations with more opportunities for success; survival; and competition (Abdul Ghani et al., 2016).

Optimizing individuals' performance should be taken into consideration when top management forms the overall organizational performance improvement strategies. Such strategies start from top management but the outcomes are achieved from the employees at their different levels, as they represent the foundation of the overall organizational performance (Ahmad et al., 2015; Kassahun, 2007).

Employee performance is represented by how employees behave; their attitude at the workplace; how well they perform their job responsibilities as well as tasks they are obligated to do; and their job outcomes (Dessler, 2017). Employee performance is influenced by the demands and requirements of the job, it is also influenced by the provided job resources; such resources include the ones provided by the organization itself, in addition to the personal resources that come from the employee himself (Bakker \& Demerouti, 2007).

\section{Suggested Citation}

Ghaleb, M., Ordun, G. (2021). The Mediating Role of Motivation Between Brand Citizenship Behavior and Employee Performance: A Study of Supervisors' Perception, Journal of Business Research-Turk, 13 (2), 1227-1241. 
The job demands and responsibilities require the employees' cognitive and emotional effort, which must be supported by job resources such as appropriate salary; frequent supervisory support; and career growth. They also need to be supported by the employee's personal efficacy; physical strength; self-esteem; and optimistic thinking. Such support leads to balance the effect of the job demands and responsibilities on the employees, which in turn leads to an increase in their work engagement, as well as their contribution to the organization's goals achievement (Moon et al., 2018; Schaufeli \& Bakker, 2004). Improving job resources in addition to sustaining; promoting; and supporting the employees' motivations leads to favorable outcomes, it also helps organizations to retain the competent, qualified employees they have (Fernet et al., 2012).

Organizations should work on motivating their employees because motivation affects the employee's work quality and willingness to a particular kind of performance, which leads to performance increase and getting the best of the employee's abilities (Zámečník, 2014). Highly motivated employees are more productive; engage in tasks willingly; innovative; present high-quality outcomes; and more loyal to the organization. On the other hand, less motivated employees show less concentration on their tasks; avoid responsibilities as much as they can; and may leave the organization if they found a better opportunity (Bhatti \& Aslam, 2016).

Employees are affected by the nature of work; work context; and working environment. Improving the working environment leads to satisfied well-being motivated employees. Employees' motivation is related positively to their job satisfaction and their work quality (Sabbagha et al., 2018; Kreye, 2016; Flynn, 2011; Jordan et al., 2007).

A motivated satisfied employee develops an individual indirectly recognized behavior that supports the overall organizational performance effectively, such behavior is called an organization citizenship behavior (Lazauskaite-Zabielske et al., 2015). It is defined as, "behavioral contributions that employees provide voluntarily to their organizations, that are neither part of their job description nor a dimension of their job requirements, and cannot be easily quantified, such as cooperates with colleagues" (Organ, 2015).

Organizational citizenship behavior connects the employee-organization relationship aspects, such as organizational identification and perceived organizational support, with the service quality perceptions (Simon \& Menguc, 2002). It affects organizational effectiveness and enhances ethical behavior (Koys, 2001), and knowledge sharing between employees (Hsien et al., 2014), which in turn affects the overall organizational performance (Baker et al., 2006). Subordinates' organizational citizenship behavior is affected by their supervisors' behavior (Tepper \& Taylor, 2003).

Organizational citizenship behavior is significantly associated with internal branding (Özçelik \& Fındıklı, 2014). Internal branding indirectly leads to citizenship behavior, by enhancing employees' brand identification (Buil et al., 2016). In addition to internal branding, outsiders' perception of the organization's brand positively affects the employee's behavior (Schaarschmidt et al., 2015). Internal branding activities along with outsiders' perception of the organization's brand, leads to employees' appreciation of the organization's brand and its related beliefs and values, which in turn leads to organizations' brand citizenship behavior (King \& Grace, 2012).

This article studies the supervisors' perception of the direct effect of brand citizenship behavior and its indirect effect through motivation on their subordinates' performance. The article scope is international franchised branded organizations and international branded humanitarian or social non-governmental organizations (NGOs), that are operating in Yemen.

\section{Literature Review}

\subsection{Employee Brand Citizenship Behavior}

Brand citizenship behavior is "the intention of each employee to voluntarily exhibit certain behaviors that are not formally defined by the role expectation system, that works on strengthening the identity of the organization's brand" (Burmann et al., 2008). On the other hand, organization citizenship behavior is, "the 
intention of employees to exhibit extra-role behavior beyond their described duties, that work on supporting the effective functioning of the organization" (Nguyen et al., 2019). Brand citizenship behavior focuses on the behavior that builds a positive external perception of the organization's brand, while organizational citizenship behavior is generally considered for internal organizational structure (Nguyen et al., 2019; Burmann \& Zeplin, 2005).

Employee brand citizenship behavior is a result of internal brand management practices (Javid et al. 2016). It is an indicator of the strength of the organization's brand, it is also an indicator of the employees' preparation of delivering the brand values and promise (King \& Grace, 2012). Internal branding activities lead to employee brand commitment, which in turn leads to employee brand citizenship behavior (Porricelli et al. 2014).

Employees who are engaged in the organization's internal branding activities have more brand knowledge and brand identification, which impact their performance and lead them to brand citizenship behavior (Ngo et al., 2019; Dechawatanapaisal, 2019). An employee with higher perceptions of the organization's brand values; works on service improvement; creates new ideas for brand development; and presents brand citizenship behavior (Kim et al., 2019). Additionally, an employee who has trust in the organization's brand is more committed and more likely to have brand citizenship behavior (Erkmen \& Hancer, 2015).

Employee brand psychological ownership leads to employee brand citizenship behavior, it is a psychological experience that makes employees produce positive brand cognitions and positive brand attitudes, such as ownership feelings toward the organization's brand (Ansari \& Kashif, 2019; Chang et al, 2012). This feeling of psychological ownership strengthens the bonds between the employee and the organization's brand, it reflects positively on employees' attitude toward the brand; affects the employee's perceived brand image, which leads to employee brand citizenship behavior (Hoppe, 2018).

Employee brand endorsement; brand understanding; and brand knowledge are important factors of employee brand citizenship behavior (Piehler, 2018). This research focuses on the output of employee brand citizenship behaviors and studies its impact on employee performance from a supervisors' perception, by testing the following hypothesis:

H1. Brand citizenship behavior significantly impacts employee performance.

\subsection{Motivation (Intrinsic and Extrinsic)}

Motivation is "the process that explains an individual's intensity, direction, and persistence of effort directed to achieving a goal" (Robbins \& Judge, 2017), it has several types such as intrinsic, and extrinsic motivations (Kuvaas et al., 2017). "Intrinsic motivation is the desire of performing an activity for its own sake, to experience the pleasure and satisfaction inherent in the activity" (Deci et al., 1989). On the other hand "extrinsic motivation is the desire to perform an activity for the purpose of having positive consequences such as an incentive or avoiding negative consequences such as a punishment" (Deci \& Ryan, 2000).

Intrinsic motivation works on lifting employees' working morale, it makes them initiate their own behavior and select their own approaches for achieving goals, they consider the task itself as their own reward (Demircioglu \& Chen, 2019; Chen et al., 2018). It is represented by the "employee's needs to challenge, to control, to satisfy curiosity and even to fulfill fantasy" (Lau \& Roopnarain, 2014). It has a relation with innovative behavior, and it is crucial for employee creativity, it also predicts the performance quality. (Saether, 2019). Additionally, intrinsic motivation affects the employees' self-fulfillment and feeling of accomplishment, which leads to job satisfaction (Araslı et al. 2014)

Intrinsically motivated employees exhibit greater interests and efforts to work; they have the ability for working innovatively; they are more involved in their jobs; they also, demonstrate greater goal achievement and desirable outcomes (Saether, 2019; Arasli et al. 2014). 
The working environment affects intrinsic motivation, it enhances the employees' desire to do the right thing and associates it with a sense of enjoyment. A working environment that has a culture of respect; recognition; autonomy; and trust, enhances the employees' intrinsic motivation (Steg, 2016). Such an environment also increases employees' engagement; persistence; learning; and ultimately performance (Zell et al., 2017).

Dysvik \& Kuvaas, (2011), found that intrinsic motivations moderate the effect of employees' perceived job autonomy on employee performance. On the other hand, Gkorezis \& Kastritsi (2017) found that when the organizations do not level up to their employees' expectations, their level of boredom is going to increase, which in turn leads to a decrease in their intrinsic motivation.

Intrinsic motivations predict organization citizenship behavior; it leads to a high level of job satisfaction; increase job performance; and affective commitment to the organization (Lazauskaite-Zabielske et al., 2015; Karatepe \& Tekinkus, 2006).

This research concentrates on the intrinsic motivations' mediating role between organization's brand citizenship behavior and employee performance, from a supervisors' perception, by testing the following hypothesis:

H2. Intrinsic Motivation significantly mediates the impact of brand citizenship behavior on employee performance, as the following:

(a) Brand citizenship behavior significantly influences intrinsic motivation.

(b) Intrinsic motivation significantly influences employee performance.

Extrinsic motivation is represented by "the satisfaction of individual needs mainly by monetary compensation" (Osterloh \& Frey, 2000), it refers to "the act of doing something because it leads to a distinct outcome" (Gago-Rodríguez \& Purdy, 2015; Ryan \& Deci, 2000). The attitude of extrinsically motivated individuals is driven by outcomes, such type of motivation leads to different behavior and performance than the intrinsic one (Hung et al., 2011). Externally motivated employees are motivated to perform well by some kind of reward; pay; promotion, praise; or avoidance of any negative consequences. Generally, they do not enjoy the tasks (Sabbagha et al., 2018).

Employees' extrinsic motivation is affected by the use of a pay-for-performance system, based on this system, employees consider the possibility to get a higher compensation when their performance is enhanced, or risks of ending up with a lowered level of reward due to poor performance (Chang, 2003).

The recognition and appreciation of an individual's contribution to the organizational goals are connected with extrinsic motivation, such appreciation can be provided in several ways such as compensations, rewards, and even work-life balance or positive feedback and supportive leadership behavior (Kreye, 2016). Recognition from others and a stable work-life balance are considered as external rewards and affect the employee's extrinsic motivations in addition to a good salary, good benefits, or monetary gain and promotion (Chiu, 2018).

Supportive leadership behavior has an impact on employees' motivation and creativity, extrinsic motivation must be supported by leadership support and motivation, especially when an employee is responsible for tasks that require creativity (Beltrán-Martín \& Bou-Llusar, 2018; Chang \& Teng, 2017; Kanama \& Nishikawa, 2017).

Extrinsic motivation is an important predictor of organizational commitment. Extrinsically motivated employees chase desirable outcomes as much as they can and work on avoiding undesired outcomes, they feel that controlled by extrinsic motivators, so they lose control over their behavior till they feel that they are burned-out, which lead them to less commitment (Kuvaas et al., 2017; Amdan et al., 2016). 
Previous researches studied the relationship between intrinsic and extrinsic motivators' and their effect on performance: Lohmann et al. (2018), found that performance-based financing did not affect employees' intrinsic motivations. Bopp et al. (2019), also found that incentive was ineffective for intrinsically motivated workers. Liang et al. (2018), found that extrinsic incentive has positive moderating role between employee efforts and job-related task. Stringer et al. (2011), found that the effect of intrinsic motivation on employees' efforts is weak when there is a high level of extrinsic incentives.

This research concentrates on extrinsic motivation's mediating role between organization's brand citizenship behavior and employee performance, by testing the below hypothesis:

H3. Extrinsic Motivation significantly mediates the impact of brand citizenship behavior on employee performance, from a supervisors' perception, as the following:

(a) Brand citizenship behavior significantly influences extrinsic motivation.

(b) Extrinsic motivation significantly influences employee performance.

Figure 1, shows this research's conceptual framework and hypothesized structure:

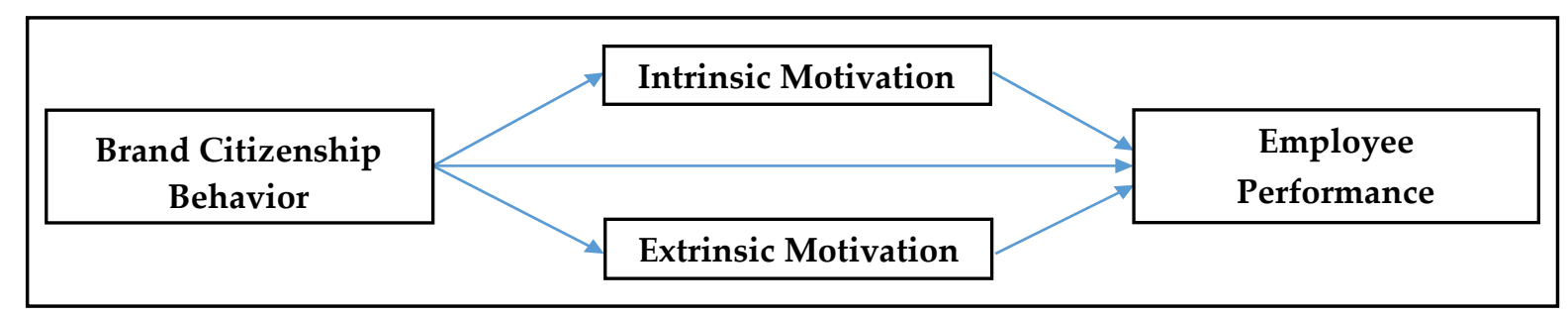

Figure 1. Conceptual framework

\section{Methodology}

\subsection{Data Collection and Participant Characteristics}

The participants of this research are Yemeni supervisors who work in international franchised branded organizations operating in Yemen. They were requested to fill an online survey which was constructed of two parts; the first part was the demographic data part, which helps in understanding more about the participants and their appropriateness to participate in this research; and the second part was about the variables related questions, which were used for hypotheses testing. The respondents were requested to answer the survey questions according to their working experience and overall observations of their subordinates.

The sample of this research has been selected using a purposive sampling method, which is a non-probability sampling methods, that targets respondents with a certain practical criteria and considered as an appropriate source of data for research (Etikan et al., 2016).

After initial data screening which includes an emphasis on that the participants work in a branded organization and removing unengaged responses, 207 responses were accepted for the research analysis, this number of responses is appropriate for structural equational modeling (SEM) analysis and leads to only $7 \%$ errors in prediction accuracy" (Varoquaux, 2018; Byrne, 2016).

Based on the demographic characteristics of the respondents, it was found that most of them represent generation X, they have an age average between 31 and 40 years old, and the majority of them have 6 subordinates or less under their supervision. 
Initial ANOVA analysis shows that there are no differences between the demographic groups' responses toward the research's variables, except one difference in the groups of educational level responses to the extrinsic motivation questions.

The details of the responses' demographic characteristics are presented in table 1.

Table 1. Respondents' Characteristics:

\begin{tabular}{llcc}
\hline \hline Descriptors & Sub-descriptors & Frequency $\mathbf{( n = 2 0 7 )}$ & Percentage (100\%) \\
\hline \multirow{3}{*}{ Age } & $21-30$ or less & 48 & $23.2 \%$ \\
& $31-40$ & 113 & $54.6 \%$ \\
\hline \multirow{3}{*}{ Education } & $41-50$ or more & 34 & $16.4 \%$ \\
& Technical institutes & 2 & $1 \%$ \\
& Bachelor degree & 148 & $71.5 \%$ \\
\multirow{2}{*}{ Number of } & Master or Ph.D. & 57 & $27.5 \%$ \\
\hline \multirow{2}{*}{ subordinates } & Less than 3 employees. & 75 & $36.2 \%$ \\
& From 3 to 6 employees. & 72 & $34.8 \%$ \\
\hline
\end{tabular}

\subsection{Measurement Scales}

The scales used for this research are English-based, they were translated to Arabic, following the process recommended by Brislin (1970), which is to be back-translated the translated questions to English by a thirdparty researcher, then compare it with the original scale.

The research's constructs were measure using a 5 point Likert scale $(1=$ Strongly disagree; 2 = Disagree; $3=$ Neutral; $4=$ Agree; $5=$ Strongly agree). These scales were used in previous studies each scale is measuring one variable and no sub-dimensions for each variable: The brand citizenship behavior scale was used in King \& Grace (2012) and was taken from Podsakoff et al (2000). The scales used for motivation were used in Kuvaas et al. (2017), the Intrinsic Motivation questions were taken from Kuvaas and Dysvik (2009), and the Extrinsic Motivation questions were adapted from Dysvik et al. (2013). Finally, the employee performance scale was used in Moon et al. (2018) and was taken from Williams and Anderson (1991).

\subsection{Analysis techniques}

The analysis techniques used for this research are Factor Analysis and Structural Equational Modeling (SEM). Factor Analysis explores then confirms the scale appropriateness for measuring the variables, especially when it is translated into another language. It confirms the fitting of the data collected to the model; the reliability of the data collected, and the validity of the measures. "It explains to what extent, observed variables are linked to their underlying factors" (Byrne, 2016).

Structural Equational Modelling (SEM) tests "various theoretical models, that hypothesize how sets of variables define constructs and how these constructs are related to each other in a quantitative manner" (Schumacker \& Lomax, 2010). Factor analysis confirms the relation between latent and observed variables while structural equational modeling (SEM) tests the structural path between variables.

\section{Analysis results and findings}

Initial analysis was implemented to ensure the suitability and appropriateness of the data for factor analysis and SEM hypothesis testing. The results of this analysis showed that the data has a normal distribution curve that shows no Skewness or Kurtosis. 


\subsection{Exploratory factor analysis (EFA), factor loading}

The analysis started with exploratory factor analysis (EFA) to find an appropriate factor loading, due to the translation of the survey questions from English to Arabic. EFA has been conducted "to determine to what extent, the observed variables are linked to their underlying factors, and to identify the minimal number of factors that account for the covariation among the observed variables" (Byrne, 2016).

During the EFA analysis of the data collected from Yemeni supervisors, survey questions with multiple loading or zero loadings had been removed, this leads to four factors, one for each variable. The initial KaiserMeyer-Olkin (KMO) factor measure was 0.90 , which is an accepted value that indicates the possibility of doing factor analysis with the amount of data collected. Bartlett's test for homogeneity of variances result was 0.000, which is an accepted value that indicates that variances are equal for all samples used in the analysis.

The results of the EFA presented in table 2, show a good exploratory factor loading, which indicates that the scales used are appropriately measuring their variables. Additional information about the mean and standard deviation of each question was added to table 2.

\subsection{Confirmatory Factor Analysis (CFA), reliability and validity assessment}

CFA works on confirming the relationship between the observed factors and their latent factor. "It tests the significance of a hypothesized factor model, whether the sample data confirm that model or not" (Schumacker \& Lomax, 2010).

The first step of CFA is to get a model fit, which includes removing the questions that have low loading on their factor and doing covariance for some other questions. This research hypothesized factor model shows a good fit $(\mathrm{CMIN} / \mathrm{DF}=1.712, \mathrm{CFI}=0.965, \mathrm{RMSEA}=0.059$, and PCLOSE $=0.128)$ and the data are appropriate for CFA and SEM analysis.

Getting a fit model allows for testing the reliability and validity of the data used in the analysis. Composite reliability shows to what level the test scores are free from measurement error or the elements of errors that occur when testing something, it has to be equal or more than $0.70(\mathrm{CR} \geq 0.70)$. On the other hand, validity "works on confirming if the latent variables are being measured accurately or not" (Muijs, 2004), accepted validity can be achieved when average variance extracted higher than or equal to 0.5 (AVE $\geq 0.5)$ and a maximum shared variance that is less than the average variance extracted (MSV > AVE). 
Table 2: Factor loading

\begin{tabular}{|c|c|c|c|}
\hline Scale & Factor loading & Mean & S. Deviation \\
\hline \multicolumn{4}{|l|}{ Brand Citizenship Behaviour (Podsakoff et al, 2000) } \\
\hline Demonstrate brand consistent behaviors. & .745 & 3.69 & .935 \\
\hline Consider the impact on the brand before acting. & .874 & 3.71 & 1.016 \\
\hline Show extra initiative to maintain brand behavior. & .817 & 3.61 & 1.036 \\
\hline Regularly recommend the brand. & .767 & 3.68 & 1.112 \\
\hline Pass on brand knowledge to new employees. & 672 & 3.85 & 1.025 \\
\hline Interested to learn more about the brand. & .848 & 3.72 & .985 \\
\hline \multicolumn{4}{|l|}{ Intrinsic Motivation (Kuvaas and Dysvik, 2009) } \\
\hline $\begin{array}{l}\text { The tasks that I do at work are themselves representing a driving power } \\
\text { in my job. }\end{array}$ & .761 & 3.80 & 1.017 \\
\hline My job is meaningful. & .727 & 4.00 & 1.012 \\
\hline My job is very exciting. & .950 & 3.64 & 1.110 \\
\hline My job is so interesting that it is a motivation in itself. & .934 & 3.61 & 1.135 \\
\hline $\begin{array}{l}\text { Sometimes I become so inspired by my job that I almost forget } \\
\text { everything else around me. }\end{array}$ & .581 & 3.68 & 1.131 \\
\hline
\end{tabular}

\section{Extrinsic Motivation (Dysvik et al. 2013)}

\begin{tabular}{|c|c|c|c|}
\hline If I am supposed to put in extra effort in my job, I need to get extra pay. & .800 & 3.25 & 1.235 \\
\hline $\begin{array}{l}\text { It is important for me to have an external incentive to strive for doing a } \\
\text { good job. }\end{array}$ & .891 & 3.51 & 1.194 \\
\hline $\begin{array}{l}\text { External incentives such as bonuses and provisions are essential for how } \\
\text { well I perform my job. }\end{array}$ & .770 & 3.14 & 1.257 \\
\hline If I had been offered better pay, I would have done a better job. & .686 & 3.37 & 1.292 \\
\hline \multicolumn{4}{|l|}{ Employee Performance (Williams and Anderson 1991) } \\
\hline Assigned duties are completed adequately. & 689 & 3.66 & 1.010 \\
\hline Tasks are performed as expected from the employee. & .888 & 3.38 & .997 \\
\hline Formal performance requirements of the job are met. & .795 & 3.53 & .979 \\
\hline Aspects of the job that are obligated to perform are never neglected. & .658 & 3.67 & 1.004 \\
\hline
\end{tabular}

The reliability and validity assessment results of the hypothesized model shown in table 3 led to conclude that the data collected and used for this research are reliable, valid, and appropriate for hypothesis testing and results generating.

Table 3. Reliability and validity assessment:

\begin{tabular}{lcccccccc}
\hline \hline & CR & AVE & MSV & MaxR(H) & EM & BCB & IM & EP \\
\hline Extrinsic Motivation (EM) & 0.870 & 0.628 & 0.030 & 0.884 & 0.793 & & & \\
Brand Citizenship Behaviour (BCB) & 0.911 & 0.630 & 0.557 & 0.913 & 0.066 & 0.794 & & \\
Intrinsic Motivation (IM) & 0.918 & 0.693 & 0.557 & 0.926 & 0.172 & 0.746 & 0.832 & \\
Employee Performance (EP) & 0.884 & 0.656 & 0.464 & 0.893 & 0.168 & 0.597 & 0.681 & 0.810 \\
\hline
\end{tabular}

\subsection{Structural Equational Modelling (SEM) Hypotheses Testing}

SEM is used when evaluating a hypothesized structural relationships model, "it is superior to regression analysis for testing indirect effects when parallel mediators are involved" (Preacher \& Hayes, 2008). The hypothesis model shown in figure 2 which presents the direct effect between brand citizenship behavior and employee performance and indirect effect with the availability of motivation, shows a good fit $(\mathrm{CMIN} / \mathrm{DF}=1.732, \mathrm{CFI}=0.964, \mathrm{RMSEA}=0.060$, and PCLOSE $=0.106)$, and is appropriate for path analysis and results generating. 
In addition to the hypothesis model fit, accepted squared multiple correlation (R-square) results were found for the model items, which were more than 0.40 . "The R-square represents the percentage of variance that is reflected by the variable predictors of the questions. It is usually between $0 \%$ and $100 \%$ and the higher the value the better the sample data matches the model" (Byrne, 2016). The accepted R-square value starts from 0.20 (Hooper et al., 2008).



Figure 2. Hypothesis structural model

The hypothesized model's SEM testing results, which are presented in table 4, indicate a significant direct effect from brand citizenship behavior to employee performance, this effect is mediated by intrinsic motivation, based on Zhao et al., (2010) research this mediating effect is considered as a complementary mediation that is consistent with the hypothesized framework. However, extrinsic motivation has no mediating role between brand citizenship behavior and employee performance.

Table 4. Hypothesis testing results:

\begin{tabular}{clcc}
\hline \hline & & P-value & Explanation \\
\hline H1 & Brand Citizenship Behavior ---> Employee Performance & 0.035 & Accepted \\
H2 & Brand Citizenship Behavior ---> Intrinsic Motivation ---> Employee Performance & 0.008 & Accepted \\
H3 & Brand Citizenship Behavior ---> Extrinsic Motivation ---> Employee Performance & 0.188 & Rejected \\
\hline
\end{tabular}

These results represent the perception of Yemeni supervisors', who are working in international franchised branded organizations, on their subordinates' performance.

\section{Discussion and conclusions}

This research aims to examine the brand citizenship behavior effect on employee performance, with the mediating role of motivation. The data analysis results show that based on the supervisors' perception, there is a direct impact of brand citizenship behavior toward employee performance in franchised branded organizations operating in Yemen. 
This result supports the finding of Ngo et al. (2019), and Dechawatanapaisal (2019), as they found that brand citizenship behavior embraces employee performance. It also supports the finding of Ansari \& Kashif (2019), which shows that employees who are proud of their organization's brand spend more effort in knowing more about the brand and have a brand psychological ownership, that leads to brand citizenship behavior, which in turn is reflected in their performance.

Working in a branded organization is a goal of a lot of people to move themselves and their experience to a new level, and get a positive reputation for working in such organizations. This leads to brand pride, which impacts the employee brand citizenship behavior, then employee attitude and performance (Helm et al., 2016).

The results also show that based on the supervisors' perception, intrinsic motivation plays a complementary mediating role between brand citizenship behavior and employee performance in franchised branded organizations operating in Yemen. This result is aligned with the finding of Saether (2019), and Arasli et al. (2014), which shows that intrinsic motivation impacts employee performance. Also, it supports the finding of Karatepe \& Tekinkus (2006), which shows that intrinsic motivation leads to a high level of job performance.

Unexpectedly the results show that based on the supervisors' perception, extrinsic motivation has no mediating role between brand citizenship behavior and employee performance in franchised branded organizations operating in Yemen. This result is aligned with the finding of Stringer et al. (2011), as they found that extrinsic motivation is negatively connected with employees' job satisfaction and employees' job performance. The result supports the finding of Amdan et al. (2016), which shows no effect from extrinsic motivation toward employee commitment and employee performance.

The intrinsic and extrinsic motivation results of this research support the finding of Singh (2016), who finds that "intrinsic factors have a bigger role in employee's motivation and are more important to them than extrinsic factors such as money". The results also support the finding of King et al. (2017), as they found that "intrinsic values have a positive impact on employee brand attitude and behavior, while extrinsic values have no significant impact".

The majority of participants' age of this research, is less than 40 years old, they are considered from the generation $X$ employees. The results of this research give an idea of their attitude, which is aligned with the generation $X$ characteristics of being more intrinsically motivated, as according to Ferres et al. (2003), generation $X$ employees are "collaborative, independent, self-sufficient and target a career that offers a balanced lifestyle.

\subsection{Implications and recommendations}

- This research provides insights into management to adopt internal brand management practices that increase their employee's brand pride and citizenship behavior, to improve their brand ownership feelings and attitude toward the brand.

- Management also should work on its employees' organizational brand knowledge, their commitment to the brand, and ensure that they are proud of working in such an organization and such a brand.

- Management should take employee intrinsic motivation as a target for overall organizational success and focus on intrinsic motivators; such as leadership style and appropriate supervision with constructive feedback, work-life balance, and other intrinsic motivators.

- The results of this research also show that extrinsic motivators are not enough for enhancing employee performance and they must be supported with intrinsic motivators. 


\subsection{Limitations and Suggestions for further researches}

- The research results cannot be generalized due to the purposive non-probability sampling method used.

- This research is limited to supervisors' perceptions of their subordinates' attitudes.

- It is limited to one type of citizenship behavior which is brand citizenship behavior.

- It is limited just to intrinsic and extrinsic motivation.

- It is limited to franchised branded organizations that operate in Yemen.

It is suggested to implement more studies in this field to understand what is affecting employee motivation and performance, and to see the employee perception of motivation. It is also suggested to implement the research in different geographical locations and to target other samples of different employees' generations.

\section{References}

Abbas, Q., \& Yaqoob, S. (2009). Effect of Leadership Development on Employee Performance in Pakistan. Pakistan Economic and Social Review, 47(2), 269-292.

Abdul Ghani, N. M., Yunus, N. M., \& Bahry, N. S. (2016). Leader's Personality Traits and Employees Job Performance in Public Sector, Putrajaya. Procedia Economics and Finance, 37, 46 - 51.

Ahmad, T., Farrukh, F., \& Nazir, S. (2015). Capacity building boost employees performance. Industrial and Commercial Training, 47(2), 61 - 66.

Alefari, M., Barahona, A. M., \& Konstantinos, S. (2018). Modelling manufacturing employees' performance based on a system dynamic approach. 51st CIRP Conference on Manufacturing Systems, 438-443.

Amdan, S., Abdul Rahman, R., Shahid, S. M., Abu Bakar, S., Khir, M. M., \& Demong, N. R. (2016). The Role of Extrinsic Motivation on the Relationship between Office Environment and Organisational Commitment. Procedia Economics and Finance, 37(1), $164-169$.

Ansari, A. R., \& Kashif, M. (2019). Few glitters are original gold Strengthening brand citizenship through identification, knowledge, and ownership in a mediating role of brand pride. Asia Pacific Journal of Marketing and Logistics, ahead-of-print, https://doi.org/10.1108/APJML-04-2018-0158.

Araslı, H., Daşkın, M., \& Saydam, S. (2014). Polychronicity and Intrinsic Motivation as Dispositional Determinants on Hotel Frontline Employees' Job Satisfaction: Do Control Variables Make a Difference? Procedia - Social and Behavioral Sciences, 109, 1395 - 1405.

Baker, T. L., Hunt, T. G., \& Andrews, M. C. (2006). Promoting ethical behavior and organizational citizenship behaviors: The influence of corporate ethical values. Journal of Business Research, 59, 849-857.

Bakker, A. B., \& Demerouti, E. (2007). The Job Demands-Resources model: state of the art. Journal of Managerial Psychology, 22(3), 309-328.

Beltrán-Martín, I., \& Bou-Llusar, J. C. (2018). Examining the intermediate role of employee abilities, motivation and opportunities to participate in the relationship between HR bundles and employee performance. BRQ Business Research Quarterly, 21, 99-110.

Bhatti, O. K., \& Aslam, U. S. (2016). Employee motivation an Islamic perspective. Humanomics, 32(1), 33-47.

Bopp, C., Engler, A., Poortvliet, P. M., \& Jara-Rojas, R. (2019). The role of farmers' intrinsic motivation in the effectiveness of policy incentives to promote sustainable agricultural practices. Journal of Environmental Management, 244, 320-327.

Brislin, R. W. (1970). Back-Translation for Cross-Cultural Research. Journal of Cross-Cultural Psychology, 1(3), 185-216. 
Buil, I., Martínez, E., \& Matute, J. (2016). From internal brand management to organizational citizenship behaviours: Evidence from frontline employees in the hotel industry. Tourism Management, 57, 256271.

Burmann, C., \& Zeplin, S. (2005). Building brand commitment: A behavioural approach to internal brand management. Journal of Brand Management, 12, 279-300.

Burmann, C., Zeplin, S., \& Riley, N. (2008). Key determinants of internal brand management success: An exploratory empirical analysis. Journal of Brand Management, 16(4), 264-284.

Byrne, B. M. (2016). Structural Equation Modeling with Amos: Basic Concepts, Applications, and Programming (3ed ed.). New York: Routledge.

Chang, A., Chiang, H.-H., \& Han, T.-S. (2012). A multilevel investigation of relationships among brandcentered HRM, brand psychological ownership, brand citizenship behaviors, and customer satisfaction. European Journal of Marketing, 46(5), 626-662.

Chang, E. (2003). Composite effects of extrinsic motivation on work effort: case of Korean employees. Journal of World Business, 38, 70-79.

Chang, J.-H., \& Teng, C.-C. (2017). Intrinsic or extrinsic motivations for hospitality employees' creativity: The moderating role of organization-level regulatory focus. International Journal of Hospitality Management, 60(1), 133-141.

Chen, C.-A., Chen, D.-Y., \& Xu, C. (2018). Applying Self-Determination Theory to Understand Public Employee's Motivation for a Public Service Career: An East Asian Case (Taiwan). Public Performance \& Management Review, 41(2), 365-389.

Chiu, H. H. (2018). Employees' Intrinsic and Extrinsic Motivations in Innovation Implementation: The Moderation Role of Managers' Persuasive and Assertive Strategies. Journal of Change Management, 18(3), 218-239.

Dechawatanapaisal, D. (2019). Internal branding and employees' brand outcomes: do generational differences and organizational tenure matter? Industrial and Commercial Training, 51(4), 209-227.

Deci, E. L., \& Ryan, R. M. (2000). The "What" and "Why" of Goal Pursuits: Human Needs and the SelfDetermination of Behavior. Psychological Inquiry, 11(4), 227-268.

Deci, E. L., Connell, J. P., \& Ryan, R. M. (1989). Self-determination in a work organization. Journal of Applied Psychology, 74(4), 580-590.

Demircioglu, M. A., \& Chen, C.-A. (2019). Public employees' use of social media: Its impact on need satisfaction and intrinsic work motivation. Government Information Quarterly, 36(1), 51-60.

Dessler, G. (2017). Human Resource Management (15th ed.). USA: Pearson Education, Inc.

Dysvik, A., \& Kuvaas, B. (2011). Intrinsic motivation as a moderator on the relationship between perceived job autonomy and work performance. European Journal of Work and Organizational Psychology, 20(3), 367387.

Dysvik, A., Kuvaas, B., \& Gagné, M. (2013). An investigation of the unique, synergistic, and balanced relationships between basic psychological needs and intrinsic motivation. Journal of Applied Social Psychology, 43(5), 1050-1064.

Erkmen, E., \& Hancer, M. (2015). Linking brand commitment and brand citizenship behaviors of airline employees: "The role of trust". Journal of Air Transport Management, 42, 47-54.

Etikan, I., Musa, S. A., \& Alkassim, R. S. (2016). Comparison of Convenience Sampling and Purposive Sampling. American Journal of Theoretical and Applied Statistics, 5(1), 1-4.

Fernet, C., Austin, S., \& Vallerand, R. J. (2012). The effects of work motivation on employee exhaustion and commitment: An extension of the JD-R model. Work \& Stress, 26(3), 213-229.

Ferres, N., Travaglione, A., \& Firns, I. (2003). Attitudinal Differences Between Generation-X and Older Employees. International Journal of Organisational Behaviour, 6(3), 320-333. 
Flynn, S. (2011). Can you directly motivate employees? Exploding the myth. Development and Learning in Organizations: An International Journal, 25(1), 11 - 15.

Gago-Rodríguez, S., \& Purdy, D. E. (2015). The effects of budgetary knowledge and extrinsic motivation on the importance that managers attribute to their budgets. Spanish Journal of Finance and Accounting / Revista Espanola de Financiacion y Contabilidad, 44(1), 47-71.

Gkorezis, P., \& Kastritsi, A. (2017). Employee expectations and intrinsic motivation: work-related boredom as a mediator. Employee Relations, 39(1), 100-111.

Helm, S. V., Renk, U., \& Mishra, A. (2016). Exploring the impact of employees' self-concept, brand identification and brand pride on brand citizenship behaviors. European Journal of Marketing, 50(1/2), 58-77.

Hooper, D., Coughlan, J., \& Mullen, M. R. (2008). Structural Equation Modelling: Guidelines for Determining Model Fit. Electronic Journal of Business Research Methods, 6(1), 53-60.

Hoppe, D. (2018). Linking employer branding and internal branding: establishing perceived employer brand image as an antecedent of favourable employee brand attitudes and behaviours. Journal of Product $\mathcal{E}$ Brand Management, 27(4), 452-467.

Hsien, L., Pei, N. F., Yung, P. C., \& Sheng, C. T. (2014). A Study on the Correlations between Knowledge Sharing Behavior and Organizational Citizenship Behavior in Catering Industry: The Viewpoint of Theory of Planned Behavior. The Anthropologist, 17(3), 873-881.

Hung, S.-Y., Durcikova, A., Lai, H.-M., \& Lin, W.-M. (2011). The influence of intrinsic and extrinsic motivation on individuals' knowledge sharing behavior. Int. J.Human-ComputerStudies, 69(1), 415-427.

Javid, H., Monfared, F. S., \& Aghamoosa, R. (2016). Internal Brand Management Relationship with Brand Citizenship Behavior, Job Satisfaction and Commitment in Saipa Teif Company. Procedia Economics and Finance, 36, $408-413$.

Jordan, M. H., Schraeder, M., Management, T. W., Feild, H. S., \& Armenakis, A. A. (2007). Organizational Citizenship Behavior, Job Attitudes, and the Psychological Contract. Military Psychology, 19(4), 259271.

Kanama, D., \& Nishikawa, K. (2017). Does an extrinsic reward for R\&D employees enhance innovation outcomes? Evidence from a Japanese innovation survey. RED Manage, 47, 198-211.

Karatepe, O. M., \& Tekinkus, M. (2006). The effects of work-family conflict, emotional exhaustion, and intrinsic motivation on job outcomes of front-line employees. International Journal of Bank Marketing, 24(3), 173193.

Kassahun, T. (2007). Management Practices as Leverages of Employee Performance. Indian Journal of Industrial Relations, 42(3), 332-354.

Kim, S., Kim, P. B., Kim, S., \& Kruesi, M. A. (2019). An examination of the progressive effects of hotel frontline employees' brand perceptions on desirable service outcomes. International Journal of Hospitality Management, 84, 1-9.

King, C., \& Grace, D. (2012). Examining the antecedents of positive employee brand-related attitudes and behaviours. European Journal of Marketing, 46(3/4), 469-488.

King, C., Murillo, E., \& Lee, H. (2017). The effects of generational work values on employee brand attitude and behavior: A multi-group analysis. International Journal of Hospitality Management, 66, 92-105.

Koys, D. J. (2001). The Effects of Employee Satisfaction, Organizational Citizenship Behavior, and Turnover on Organizational Effectiveness: A Unit-Level, Longitudinal Study. Personnel Psychology, 54, 101-114.

Kreye, M. E. (2016). Employee motivation in product-service system providers. Production Planning \& Control, 27(15), 1249-1259.

Kuvaas, B., \& Dysvik, A. (2009). Perceived investment in employee development, intrinsic motivation, and work performance. Human Resource Management Journal, 19(3), 217-236.

Kuvaas, B., Buch, R., Weibel, A., Dysvik, A., \& G.L., C. N. (2017). Do intrinsic and extrinsic motivation relate differently to employee outcomes? Journal of Economic Psychology, 61, 244-258. 
Lau, C. M., \& Roopnarain, K. (2014). The effects of nonfinancial and financial measures on employee motivation to participate in target setting. The British Accounting Review, 46(1), 228-247.

Lazauskaite-Zabielske, J., Urbanaviciute, I., \& Bagdziuniene, D. (2015). The role of prosocial and intrinsic motivation in employees' citizenship behaviour. Baltic Journal of Management, 10(3), 345-365.

Liang, H., Wang, M.-M., Wang, J.-J., \& Xue, Y. (2018). How intrinsic motivation and extrinsic incentives affect task effort in crowdsourcing contests: A mediated moderation model. Computers in Human Behavior, $81,168-176$.

Lohmann, J., Muula, A. S., Houlfort, N., \& De Allegri, M. (2018). How does performance-based financing affect health workers' intrinsic motivation? A Self-Determination Theory-based mixed-methods study in Malawi. Social Science \& Medicine, 208, 1-8.

Moon, T.-W., Youn, N., Hur, W.-M., \& Kim, K.-M. (2018). Does employees' spirituality enhance job performance? The mediating roles of intrinsic motivation and job crafting. Current Psychology, 1-17.

Muijs, D. (2004). Doing Quantitative Research in Education with SPSS (1st ed.). London: Sage Publications.

Ngo, L. V., Nguyen, N. p., Huynh, K. T., Gregory, G., \& Cuong, P. H. (2019). Converting internal brand knowledge into employee performance. Journal of Product \& Brand Management, ahead-of-print, https://doi.org/10.1108/JPBM-10-2018-2068.

Nguyen, L. T., Lu, V. N., Hill, S. R., \& Conduit, J. (2019). The mediating role of brand knowledge on employees' brand citizenship behaviour: Does organizational tenure matter? Australasian Marketing Journal, 27, 169-178.

Organ, D. W. (2015). Organizational Citizenship Behavior. International Encyclopedia of the Social E Behavioral Sciences, 17, 317-321.

Osterloh, M., \& Frey, B. S. (2000). Motivation, Knowledge Transfer, and Organizational Forms. Organization Science, 11(5), 538-550.

Özçelik, G., \& Fındıklı, M. (2014). The Relationship between Internal Branding and Organizational Citizenship Behaviour: The Mediating Role of Person-Organization Fit. Procedia - Social and Behavioral Sciences, 150, 1120 - 1128.

Piehler, R. (2018). Employees' brand understanding, brand commitment, and brand citizenship behaviour: a closer look at the relationships among construct dimensions. Journal of Brand Management, 25(3), 217234.

Podsakoff, P. M., MacKenzie, S. B., Paine, J. B., \& Bachrach, D. G. (2000). Organizational citizenship behaviors: a critical review of the theoretical and empirical literature and suggestions for future research. Journal of Management, 26(3), 513-563.

Porricelli, M. S., Yurova, Y., Abratt, R., \& Bendixen, M. (2014). Antecedents Of Brand Citizenship Behavior In Retailing. Journal of Retailing and Consumer Services, 21, 745-752.

Preacher, K. J., \& Hayes, A. F. (2008). Asymptotic and resampling strategies for assessing and comparing indirect effects in multiple mediator models. Behavior Research Methods, 40(3), 879-891.

Robbins, S. P., \& Judge, T. A. (2017). Organizational Behavior (17th ed.). Harlow: Pearson Education Limited.

Rusu, G., Avasilcăi, S., \& Huțu, C.-A. (2016). Organizational Context Factors Influencing Employee Performance Appraisal: A Research Framework. Procedia - Social and Behavioral Sciences, 221, 57 - 65.

Ryan, R. M., \& Deci, E. L. (2000). Intrinsic and Extrinsic Motivations: Classic Definitions and New Directions. Contemporary Educational Psychology, 25(1), 54-67.

Sabbagha, M. D., Ledimo, O., \& Martins, N. (2018). Predicting staff retention from employee motivation and job satisfaction. Journal of Psychology in Africa, 28(2), 136-140.

Saether, E. A. (2019). Motivational antecedents to high-tech R\&D employees' innovative work behavior: Selfdetermined motivation, person-organization fit, organization support of creativity, and pay justice. Journal of High Technology Management Research, 30(1), 1-12. 
Schaarschmidt, M., Walsh, G., \& Ivens, S. (2015). Perceived External Reputation as a Driver of Organizational Citizenship Behavior: Replication and Extension. Corporate Reputation Review, 18(4), 314-336.

Schaufeli, W. B., \& Bakker, A. B. (2004). Job demands, job resources, and their relationship with burnout and engagement: a multi-sample study. Journal of Organizational Behavior, 25, 293-315.

Schumacker, R. E., \& Lomax, R. G. (2010). A Beginner's Guide to Structural Equation Modeling (3rd ed.). New York: Taylor and Francis Group, LLC.

Simon, B. J., \& Menguc, B. (2002). The employee-organization relationship, organizational citizenship behaviors, and superior service quality. Journal of Retailing, 78, 131-146.

Singh, R. (2016). The Impact of Intrinsic and Extrinsic Motivators on Employee Engagement in Information Organizations. Journal of Education for Library and Information Science, 57(2), 197-206.

Steg, L. (2016). Values, Norms, and Intrinsic Motivation to Act Proenvironmentally. Annual Review of Environment and Resources, 41, 277-292.

Stringer, C., Didham, J., \& Theivananthampillai, P. (2011). Motivation, pay satisfaction, and job satisfaction of front-line employees. Qualitative Research in Accounting \& Management, 8(2), 161-179.

Tepper, B. J., \& Taylor, E. C. (2003). Relationships among Supervisors' and Subordinates' Procedural Justice Perceptions and Organizational Citizenship Behaviors. The Academy of Management Journal, 46(1), 97105.

Varoquaux, G. (2018). Cross-validation failure: Small sample sizes lead to large error bars. NeuroImage, 180, 68-77.

Williams, L. J., \& Anderson, S. E. (1991). Job satisfaction and organizational commitment as predictors of organizational citizenship and in-role behaviors. Journal of Management, 17(3), 601-617.

Zámečník, R. (2014). The measurement of employee motivation by using multi-factor statistical analysis. Procedia - Social and Behavioral Sciences, 109, 851 - 857.

Zhao, X., Lynch, J. G. \& Chen, Q., 2010. Reconsidering Baron and Kenny: Myths and Truths about Mediation Analysis. Journal of Consumer Research, 37(2), pp. 197-206.

Zell, E., Strickhouser, J. E., \& Alicke, M. D. (2017). Local dominance effects on self-evaluations and intrinsic motivation. Self and Identity, 16(5), 629-644. 